\title{
CONTEXT APPROACH FOR ELECTRIC GRID CONTROL
}

\author{
I. V. VERBUTSKYI ${ }^{1 *}$, A. G.KYSELOVA ${ }^{2}$ \\ ${ }^{1}$ The department of Industrial Electronics, Faculty of Electronics, National Technical University of Ukraine "Kyiv Polytechnic \\ Institute", Kyiv, UKRAINE \\ ${ }^{2}$ The department of System Design, Educational Scientific Complex "IASA", National Technical University of Ukraine "Kyiv \\ Polytechnic Institute", Kyiv, UKRAINE \\ "email:verbitskiy@bigmir.net
}

\begin{abstract}
The necessity of using the parallel connection of renewable energy sources (RES) at an electric grid which leads to a complicated control is shown. The control improvement on basis additional data about the environment and the grid infrastructure is described. The data formalizing to a context for decreasing calculation complexity and using expert knowledge is proposed. The example of context using is shown. A hierarchical control system on basis variety of data representation is shown. A flexible structure of control unit is proposed.
\end{abstract}

Keywords: context, hierarchical control system, expert knowledge, rules, renewable energy sources

\section{КОНТЕКТНИЙ ПІДХІД КЕРУВАННЯ СИСТЕМОЮ ЕЛЕКТРОЖИВЛЕННЯ}

\section{Є. В. ВЕРБИЦЬКИЙ ${ }^{*}$, А. Г. КИСЕЛЬОВА ${ }^{2}$}

\author{
${ }^{1}$ Кафедра промислової електроніки, факультет електроніки, НТУУ «КПІ», Київ, УКРАЇНА \\ ${ }^{2}$ Кафедра системного проектування, ННК «Інститут прикладного системного аналізу», НТУУ «КПІ», Київ, УКРАЇНА \\ *email:verbitskiy@bigmir.net
}

\begin{abstract}
АНОТАЦІЯ Використання відновлювальних джерел енергї (ВДЕ) має ряд особливостей, які пов'язані з їх малою та нестабільною в часі вихідною потужністю. Тому виникає необхідність їх паралельного під'єднання для забезпечення необхідної вихідної потужності та встановлення акумулятора для перерозподілу енергії, відібраної від ВДЕ, в часі. Можливість паралельної роботи різнотипних ВДЕ в системі електроживлення забезпечується встановленням на їх виході перетворювачів електричної енергії, які виконують функцію узгоджувального пристрою і можуть працювати в режимі джерела струму, напруги або потужності. Керування перетворювачами електроенергії здійснюється з використанням гетерогенних даних про навколишне середовище (потужність сонячного випромінювання, швидкість $i$ напрям вітру, температура, вологість тощо), режими роботи силового обладнання (просторовий розподіл джерел енергії і їх вихідна потужність, рівень заряду акумуляторів, обсяг втрат енергії в системі) $і$ потужності споживачів. Покращення ефективності керування перетворювачами системи електроживлення можливе за умови накопичення, обробки та інтеграції даних від усіх доступних давачів системи. Однак при збільшенні кількості ВДЕ, які входять до складу системи електроживлення, з одного боку експоненційно зростає обсяг оброблюваних і транспортованих даних між вузлами системи, з іншого боку - через зростання кількості параметрів, які входять до закону керування, його загальний вигляд значно ускладнюсться і не може бути виведений автоматично. Тому для керування також використовують знання експертів, які переважно представлені у вигляді правил, щзо дозволить забезпечити: зменшення обсягу транспортованих і оброблюваних даних; збільшення гнучкості керування системою електроживлення; моживість вибору стратегії керування залежно від наявної інформації про систему і обсягом виміряних даних.
\end{abstract}

Ключові слова: контекст, ієрархічний принцип керування, експертні знання, правила керування, відновлювальні джерела енергії

\section{Introduction}

The RES have nonstable output power, therefore they are connected in parallel to an electric grid to ensure the required output power. Redistribution RES energy in time is provided by a battery installing. The RES parallel work are achieved by using matched devices on basis power converters which work in voltage, current or power source modes [1,2]. Heterogeneous data of environment (solar radiation, wind speed, and direction, temperature, humidity), power equipment modes (the RES spatial arrangement, its output power, the battery power level, power loss level), load's power are used for converters control.
The grid's sensors data accumulation, processing, and integration allow improving the control effectiveness. But increasing the RES number causes to an exponential increase of the transmitted and processing data. The electric grid control law also complicated due to increasing of control parameters. In this case, for the control may be used rules on basis expert knowledge [3]. Such control system has a hierarchical structure and consists of autonomous units. The top-level hierarchy control system unit's deal with general processes of the overall grid. The expert rules used by reason of control complexity on this level. The lowlevel control units subordinate to top-level units and manage of the separate equipment use a PID controller law or more advanced laws on basis time series (TS). Interaction 
formalization between a two type units is an urgent problem for such control systems of the electric grid.

\section{Goal}

The TS processing sequence consist of several procedures: fixing the values of control parameters by thesensors and obtaining the TS, the analysis of the reliability of the obtaining the TS data, determining the preferable TS length, the TS filtration, approximation, and prediction [4].

The low-level control units may use the TS but for the top-level units is necessary data formalizing because it allows reduce the amount of the processing data, increase intelligent of the control, use expert knowledge. For instance, it is possible to transmit a signal integral indicators (average value, RMS, trend) instead its TS. The subsequent generalization may be performed by the signal extrapolation with a predetermined reliability. This information allows determining the signal changing over time more accurately and additionally decrease of the transmitted information between units.

\section{The statement of the base material}

The data reliability is an important aspect for the electric grids with high-level electromagnetic noise. A preliminary data processing is desirable in this case. Static methods may use here, especially a least square method (LSM) [5]. The LSM allows defining a predict parameters with the minimal standard deviation (SD). The sequence of data processing is shown in Table 1.

Table 1. the sequence of data processing

\begin{tabular}{|c|c|}
\hline $\begin{array}{l}\text { Step } 1 \\
\text { Approximation the TS by polynomial function } \\
y=f\left(t, c_{0}, c_{1}, \ldots, c_{n}\right) \text {, where } c_{k} \text { is constant coefficients, for instance } y=c_{2} t^{2}+ \\
c_{1} t+c_{0}\end{array}$ & $\begin{array}{l}\text { Step } 2 \\
\text { A standard deviation calculation for the TS values } \sigma_{y} \text { and the } \\
\text { parameters estimation of approximation function } \sigma_{c k}\end{array}$ \\
\hline current interval & $\begin{array}{l}\sigma_{y}=\sqrt{\frac{1}{n} \sum_{k=1}^{n}\left(y(k \Delta t)-y_{k}\right)^{2}} ; \\
\sigma_{c k}=\frac{\sigma_{y}}{\sqrt{n}}, \\
\text { where } n \text { is the TS length }\end{array}$ \\
\hline $\begin{array}{l}\text { Step } 3 \\
\text { The function values prediction in a some predict interval with } 3 \sigma \\
\text { reliability }\end{array}$ & $\begin{array}{l}\text { Step } 4 \\
\text { The information formalization }\end{array}$ \\
\hline $\begin{array}{l}y_{\min }=\left(c_{2-3} \sigma_{\mathrm{ck}}\right) t^{2}+\left(c_{1-3} \sigma_{\mathrm{ck}}\right) t+\left(c_{0-3} \sigma_{\mathrm{ck}}\right) \\
y_{\max }=\left(c_{2+3} \sigma_{\mathrm{ck}}\right) t^{2}+\left(c_{1+3} \sigma_{\mathrm{ck}}\right) t+\left(c_{0+3} \sigma_{\mathrm{ck}}\right)\end{array}$ & $\begin{array}{l}\text { TS value }:=\langle\text { Decrease» } \\
\text { The rate of increase of the signal in the current } \\
\text { interval }:=\langle-2.5 . .-3.2 » \text { The signal will cross threshold in time } \\
\text { interval }:=\left\langle t_{1} . . t_{2} » \text { Average signal value }:=\left\langle A_{d} »\right.\right. \\
\mathrm{SD}=\langle\sigma »\end{array}$ \\
\hline
\end{tabular}

The TS approximation allows predict and uses signal values for control in the analytical form which minimizes storage space and transmitted rate for data. Also, the analytical form of the data helps us to use new control methods, for instance adaptive, robust or predict methods [6]. The obtained analytical functions may be formalized to a context $[7,8]$ for subsequent using to rules creation by the experts. The formalizing procedure of context deriving is shown in step 4 of Table 1.

The formalized control method on the context basis supplements the numerical TS data by knowledge about their physical meaning and relations, environment state etc. All these context data is stored in a graph which is called a grid ontology [9, 10]. For instance, we consider P-Q diagram (diagram of active $\mathrm{P}$ and reactive power $\mathrm{Q}$ ) of a reactive power compensator which is shown on fig. 1 .

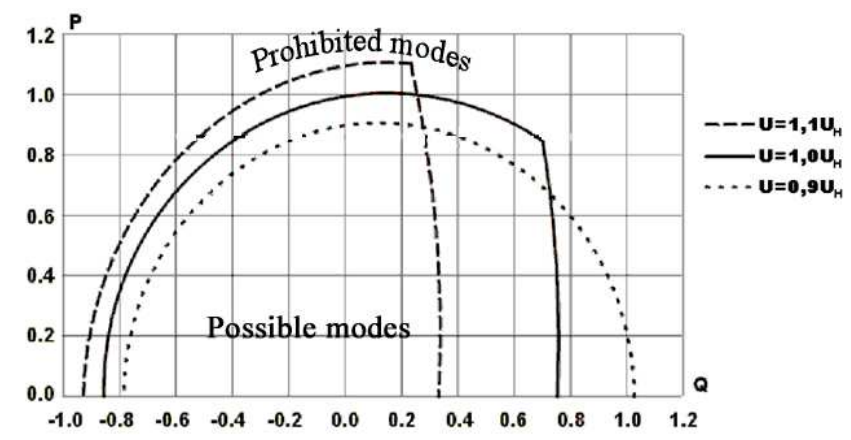

Fig. 1. - P-Q diagram of a reactive power compensator

The family of curves P-Q is threshold values for the compensator control system. If the compensator operating point is above of threshold value which corresponds to the 


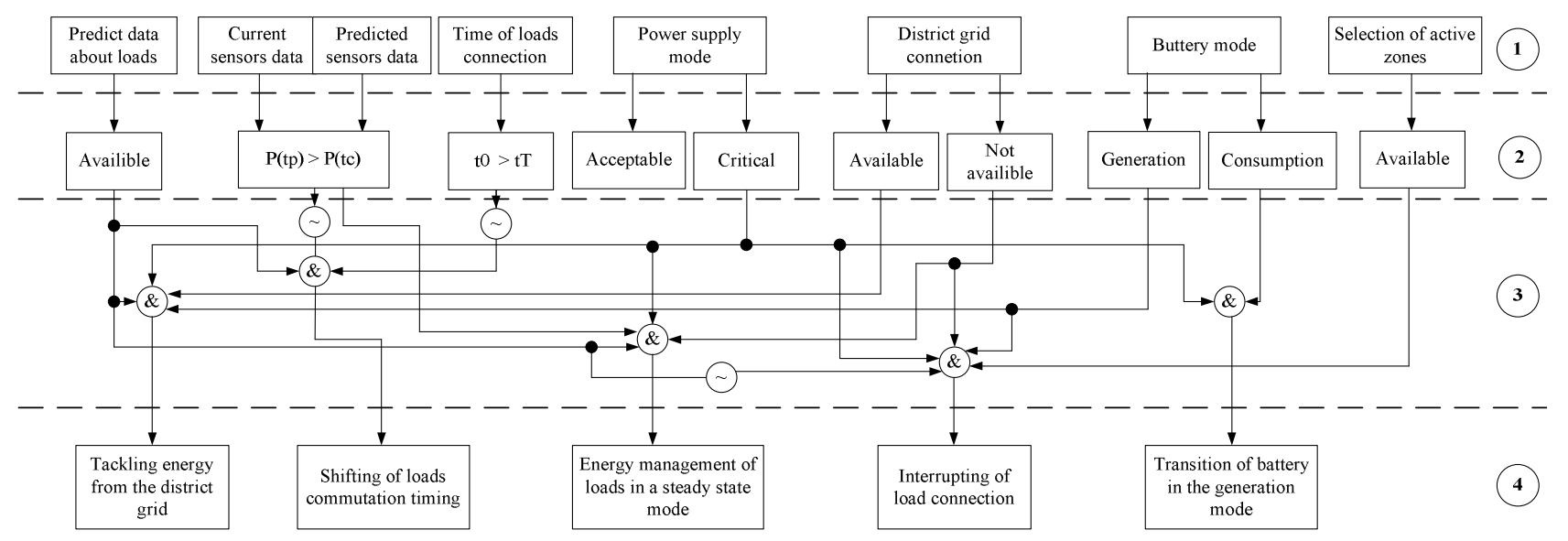

\& - AND logical operation $\odot$ - NOT logical operation

(1) - context parameters layer 2 - context attributes layer 3 - logical operators layer 4 -comand layer

Fig. 2 - The expert rule example

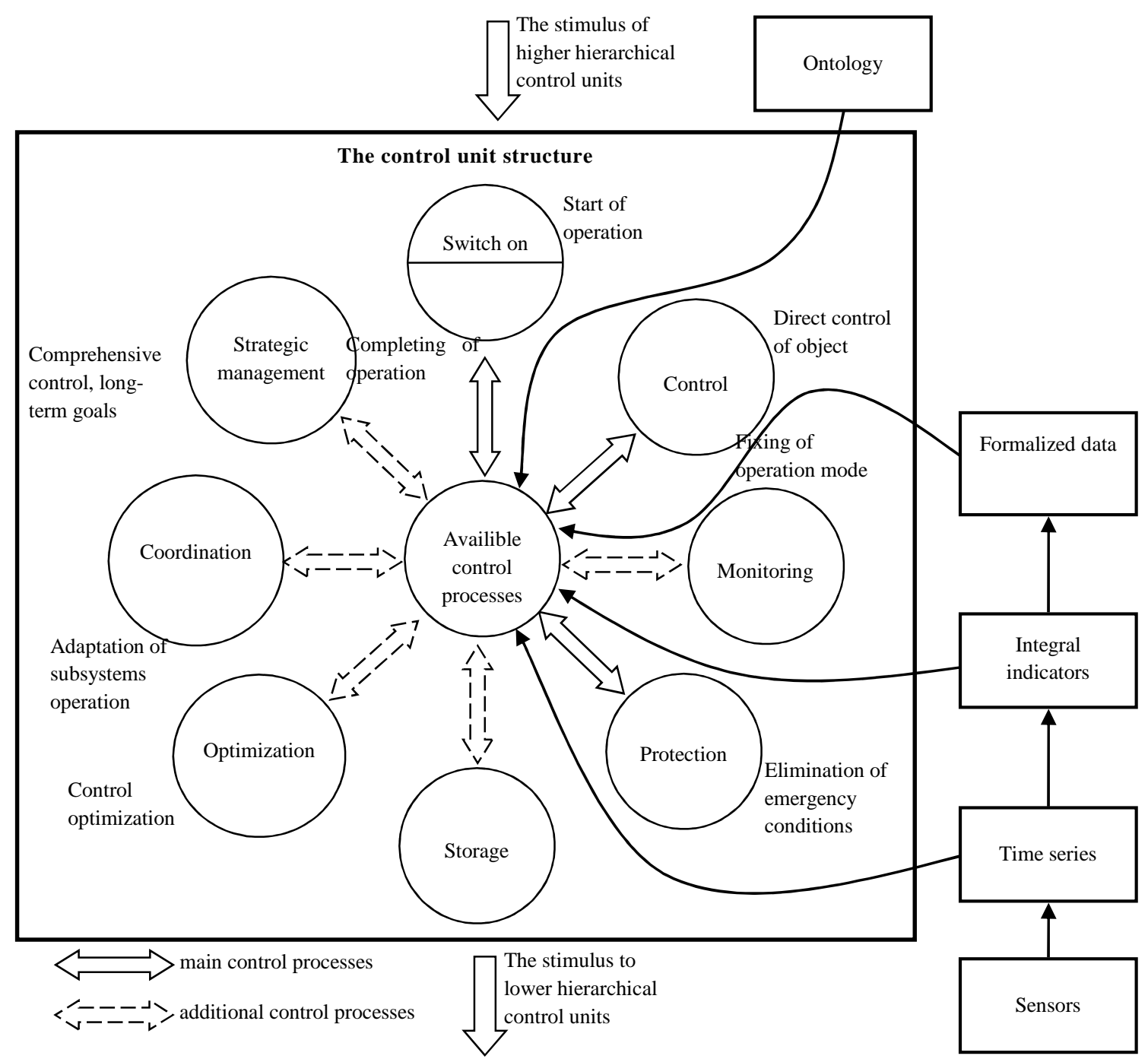

Fig. 3. - Structure of the control unit of electric grid 
compensator DC link voltage $\mathrm{U}$, the context of the current mode is «Compensator DC link voltage is:= Not enough». In another case the context has value «Compensator DC link voltage is:= Enough». If the compensator mode is unsatisfactory, a control command has to generate, for instance, «Increase DC link voltage by $10 \% »$. The prediction data make control more flexible.

They help define a time of some event «After ten seconds DC link voltage will := Not enough». The described examples of context may used like input data for rules developing. The rule example is shown on the fourth layer structure of rule is shown on fig. 2. The context parameters are on the first layer. They are "Predict data about loads", "Current sensors data" and "Predicted sensors data" etc. Some context attributes used for rules design shown on the second level, for instance, "Critical", "Available". The context attributes combined using logical operators on the third level. Control commands obtained on the fourth level. The control commands are stimulus for control units of the lower level of the hierarchy. Numerical values of stimulus may calculate directly or only set the direction of change.

\section{The discussion of the results}

Plenty of options for data formats allows choose the appropriate control method. It depends on completeness and format of the accessible information the control object, its complexity. Also additional information helps divide control on separate processes and use it depending on the context. Part of the processes are necessary, the other processes may linked if needed. A structure of the control unit is shown on fig. 3 .

\section{Conclusions}

The variety of data representation forms, additional information about the electric grid system contained in the ontology allows to use the intelligent control methods to provide such benefits:

- reducing the amount of processed and transmitted data;

- flexible control of the electric grid;

- control strategy selection depends on available information.

\section{Список літератури}

1. Кириленко, А. В. Преобразователи параметров электроэнергии в smart системах энергетики / А. В. Кириленко, Ю. И. Якименко, В. Я. Жуйков, С. П. Денесюк // Праиі інституту електродинаміки. Спец. випуск. - Київ. - 2010. - С. 17-23.

2. Жуйков, В. Я. Формирование синусоидального напряжения разнотипными источниками энергии / В. Я. Жуйков, Е. В. Вербицкий, Е. С. Осипенко // Энергосбережение энергетика энергоаудит. - 2013. №8 (114). - C. 104-106.

3. Firat, A. Information Integration Using Contextual Knowledge and Ontology Merging [Web]: $\mathrm{PhD}$ Thesis: 27.08.03: defended Sep. 2003. MIT, 2003. 151p. URL: http://www.mit.edu/ bgrosof/paps/phd-thesis-aykut-firat.pdf (access date: 29.05.2009).

4. Box, G. Time Series Analysis: Forecasting and Control / G. Box, G. Jenkins, G. Reinsel // Wiley. - 2008. - 784 p.

5. Swerling, P. Modern state estimation methods from the viewpoint of the method of least squares. Automatic Control / P. Swerling // IEEE Transactions. - 1971. - Volume 16, Issue 6. - P. 707-719. - doi:10.1109/TAC.1971.1099815.

6. Rolf Issermann Digital control systems. Fundamentals, deterministic control. - Springer-Verlag. - 1989. Volume 1. - $334 \mathrm{p}$.

7. Hong, J. Context-aware Systems: A Literature Review and Classification / J. Hong, E. Suh, S. Kim // Expert Systems with Applications. - 2008. - 36(4). - 8509-8522. doi:10.1016/j.eswa.2008.10.071.

8. Вербицкий, Е. В. Использование контекстных данных при управлении распределенной сетью электропитания / Е. В. Вербицкий, А. Г. Киселева // Технічна електродинаміка. - 2016. - № 1. - С. 55-59.

9. Zhuikov, V. Integration of context-aware control system in microgrid / V. Zhuikov, A. Kyselova // in Electronics and Nanotechnology (ELNANO), IEEE XXXIII International Scientific Conference. - 2013. - P. 386-390. doi:10.1109/ELNANO.2013.6552029.

10. Кисельова, А. Г. Регуляризація контекстних даних при керуванні автономними системами електроживлення/ А. Г. Кисельова, Г. Д. Кисельов // Вісник НТУ «ХПI», Серія: Нові рішення в сучасних технологіях. - Харків: НТУ «ХПІ». - 2016. - № 12 (1184). - С. 125-130. doi:10.20998/2413-4295.2016.12.18

\section{Bibliography (transliterated)}

1. Kirilenko, A. V., Yakimenko, U. I., Zhuykov, V. Ya., Denesyuk, S. P. Preobrazovateli parametrov elektroenergii v smart sistemakh energetiki [Converters parameters in smart electricity system]. Pratsi institutu elektrodinamiki. Spets. vipusk [Pratsi Instytutu Elektrodynamiky. Spetsialnyi vypusk], 2010, 17-23.

2. Zhuykov, V. Ya., Verbiskiy, Ye. V., Osipenko, Ye. S. Sinusoidal voltage generation by energy sources of different type. Energosberezhenie energetica energoaudit, 2013, 8(114), 104-106.

3. Firat A. Information Integration Using Contextual Knowledge and Ontology Merging [Web]: PhD Thesis: 27.08.03: defended Sep. 2003. MIT, 2003. 151p. URL: http://www.mit.edu/ bgrosof/paps/phd-thesis-aykut-firat.pdf (access date: 29.05.2009).

4. Box, G., Jenkins, G., Reinsel, G. Time Series Analysis: Forecasting and Control, Wiley, 2008, 784 p.

5. Swerling, P. Modern state estimation methods from the viewpoint of the method of least squares. Automatic Control, IEEE Transactions, 1971, 6(16), 707-719, doi:10.1109/TAC.1971.1099815

6. Rolf Issermann. Digital control systems. Volume 1: Fundamentals, deterministic control. Springer-Verlag, 1989, $334 \mathrm{p}$.

7. Hong, J., Suh, E., Kim, S. Context-aware Systems: A Literature Review and Classification. Expert Systems with Applications, 2008, 36(4), 8509-8522, doi:10.1016/j.eswa. 2008.10.071.

8. Verbytskyi, I. V., Kyselova, A. G. Application of contextual data for control of distributed power grid. Tekhnichna elektrodynamika, 2016, 1, 55-59.

9. Zhuikov, V., Kyselova, A. Integration of context-aware control system in microgrid. in Electronics and Nanotechnology (ELNANO), 2013 IEEE XXXIII 
International Scientific Conference, 2013, 386-390, doi:10.1109/ELNANO.2013.6552029.

10. Kyselova, A., Kyselov, G. Regularization of context data of autonomous power supply systems. Bulletin of NTU "KhPI".
Series: New solutions in modern technologies. - Kharkiv: NTU "KhPI", 2016, 12(1184), 125-130, doi: 10.20998/24134295.2016.12.18.

\section{About authors (Відомості про авторів)}

Verbytskyi Ievgen - Candidate of Technical Sciences (Ph. D.), Assoc. Prof., National Technical University of Ukraine "Kyiv Polytechnic Institute", 37, Prospect Peremohy, 03056, Kyiv-56, Ukraine; e-mail: verbitskiy@ bigmir.net.

Вербицький «Київський політехнічний інститут», доцент кафедри системного проектування; м.Київ, Україна; е-таil: verbitskiy@bigmir.net.

Kyselova Anna - Candidate of Technical Sciences (Ph. D.), Assoc. Prof., National Technical University of Ukraine "Kyiv Polytechnic Institute”, 37, Prospect Peremohy, 03056, Kyiv-56, Ukraine; e-mail: a.g.kyselova@ gmail.com.

Кисельова Анна Геннадї̈вна- кандидат технічний наук, Національний технічний університет України «Київський політехнічний інститут», доцент кафедри системного проектування; м.Київ, Україна; е-mail: a.g.kyselova@ gmail.com.

Please cite this article as:

Verbitskyi, I. V., Kyselova, A. G. Context approach for electric grid control. Bulletin of NTU "KhPI". Series: New solutions in modern technologies. - Kharkiv: NTU "KhPI", 2016, 18 (1190), 123-127, doi:10.20998/2413-4295.2016.18.18.

Будь ласка посилайтесь на ию статтю наступним чином:

Вербицький, Є. В. Контекстний підхід керування системою електроживлення / С. В. Вербицький, А. Г. Кисельова // Вісник НТУ «ХПІ», Серія: Нові рішення в сучасних технологіях. - Харків: НТУ «ХПІ». - 2016. - № 18 (1190). - С. $123-127$. - doi:10.20998/2413-4295.2016.18.18.

Пожалуйста ссылайтесь на эту статью следующим образом:

Вербицкий, Е. В. Контекстный подход управления системой электропитания / Е. В. Вербицкий, А. Г.Киселева // Вестник НТУ «ХПИ», Серия: Новые решения в современных технологиях. - Харьков: НТУ «ХПИ». - 2016. - № 18 (1190). C. 123-127. - doi:10.20998/2413-4295.2016.18.18.

АННОТАЦИЯ Повымение эффективности управления преобразователями системы электропитания возможно при условии накопления, обработки и интеграции данных от всех доступных датчиков системы. Однако при увеличении количества возобновляемых источников электроэнергии, которые входят в состав системы электропитания, с одной стороны растет экспоненииально объем обрабатываемых и транспортируемых данных между узлами системы, а с другой - из-за роста количества параметров, входящих в закон управления, чей общий вид значительно усложняется и не может быть выведен автоматически. Поэтому для управления необходимо использовать знания экспертов.

Ключевые слова: контекст, иерархический принцип управления, экспертные знания, правила управления, возобновляемых источников энергии 